\title{
Reflective Case Discussion (RCD) for Nurses: A Systematic Review
}

\author{
Haeril Amir*, Sudarman Sudarman \\ Faculty of Public Health, Universitas Muslim Indonesia \\ *haerilamir12@gmail.com
}

\begin{abstract}
Reflection Case Discussion is a method of professional reflection conducted by health workers, usually with nurses, RCD aims to address gaps in nursing theory and practice, expand nurse competencies and knowledge, educational and nursing needs and are an educational responsibility. The aim of this study was to determine the benefits of RCD on nurses themselves, this literature through identification from the Pubmed database, Science direct and online wiley,use the keywords 'Reflection' and 'Case' and 'Nursing'. The method of searching articles uses PICOT technique, Prism Flow diagram, abstraction and synthetic data. Through fulltext screening, double publication and eligibility, 455 research articles were found. The next step is to screen through the inclusion criteria and exclusion criteria so that the final result of the article found is 4 articles. Articles have a lot to explain about the benefits RCD for nurses, RCD can add to the knowledge of nurses, minimize the gap theory and practice so that errors can be resolved. Literature is also finding benefits RCD on nurses is increasing the professionalism of the work and cooperation among fellow colleagues. Implementation of the RCD environment of clinical very ber benefits, but there are some things usually hamper so implementation RCD can be constrained. One of the factors that $\mathrm{k}$ eterlibatan participants RCD, the activity of the participants affect the results are desired, by because of the need to do the socialization and DRK are scheduled to be implemented in routine, beside others the support and motivation of the leadership is very necessary, both managers of nursing as well as leaders of the house sick. Availability of facilities and room as well as the burden of work of nurses also become a reason of activities is often overlooked.
\end{abstract}

Keywords: Reflective Case Discussion (RCD), Nurses, Hospital, Literature Review 


\section{STRADA Jurnal Ilmiah Kesehatan}

DOI: $10.30994 /$ sjik.v9i2.306

ISSN: 2252-3847 (print); 2614-350X (online)

Vol.9 No.2 November 2020 Page.332-337

\section{BACKGROUND}

The desire of the community to get maximum service encourages health workers, including nurses, to continue to increase knowledge so that professionals work. Professionals are the needs of patients, one of the efforts to improve professionalism can be done with Reflection Case Discussion (RCD) which involves fellow work teams in hospitals, RCD has many benefits, and most importantly that RCD can increase Nurse knowledge (Amir, Irwan, \& Saleh, 2019).

RCD is a method of reflecting nurses 'clinical experience, RCD can support nurses' work (Kemenkes, 2005). RCD is also considered a Continuing Nursing Education (CNE) aimed at increasing the professionalism of health practitioners according to their competency standards (PPNI, 2016). According to the CNE Nursing and Midwifery Board of Australia or Continuing Professional Development (CPD) which is a means to increase knowledge by expanding and maintaining professionalism(Nursing and Midwifery Board of Australia., 2016). CPD begins at the level of undergraduate study and develops based on theoretical basis and practical experience through 5 levels namely: beginner, advanced beginner, competent, competent and expert(Benner, 1984). The implementation of CPD through the RCD method provides many benefits, RCD canmen push nurses to think universally, critical thinking in reducing the risk of errors based on experience( Berterö, 2010). Reflecting on practical experience through RCD is also useful to promote the emergence of new knowledge that can lead to the transformation of clinical practice of nursing (Asselin \& Fain, 2013). This literature study aimed to collect articles on RCD based on inclusion and exclusion criteria by the PICOT method.

\section{METHOD}

Study of this literature through the search results of scientific publications from 2000 -2020 using the database Pubmed, Science Direct, Wiley Online. Pubmed database search using keywords 1 " Reflection " AND " Case " AND Discussion "AND" Nursing "OR Nurse ". Found as many as 987571 articles, use the keyword 2 "Reflective" AND "Discussion" AND "Nursing" was found seba n yak 3948 article. If keywords 1 and 2 are combined then get 3949 articles . A search using the Science Direct database with the keyword " Reflection Case Discussion" was found as many as 146916 articles. A search using Wiley Online with the keywords 1 "Reflection" Anywhere "Case" Anywhere "Discussion " Anywhere "Nursing" (Alldate) found as many as 143722 articles, keyword 2 "Reflective" Anywhere "Case" Anywhere "Discussion" Anywhere "Nursing" ( Alldate) Alldate) found as many as 100234 articles. If keywords 1 and 2 are combined then 26137 articles are obtained.

The next process is screning Full text, eligibility, and double publication and based on the inclusion and exclusion criteria as follows:

1. Inclusion Criteria
a. Research article in Hospital and Health center
b. National \& International Publication
c. Full Text, Open acces and Journal article

2. Exclusion Criteria

a. Research article outside the Hospital \& Health research

b. Use languange other than English and Indonesia 


\section{STRADA Jurnal Ilmiah Kesehatan}

DOI: $10.30994 /$ sjik.v9i2.306

ISSN: 2252-3847 (print); 2614-350X (online)

Vol.9 No.2 November 2020 Page.332-337

The article search results can be described as follows:

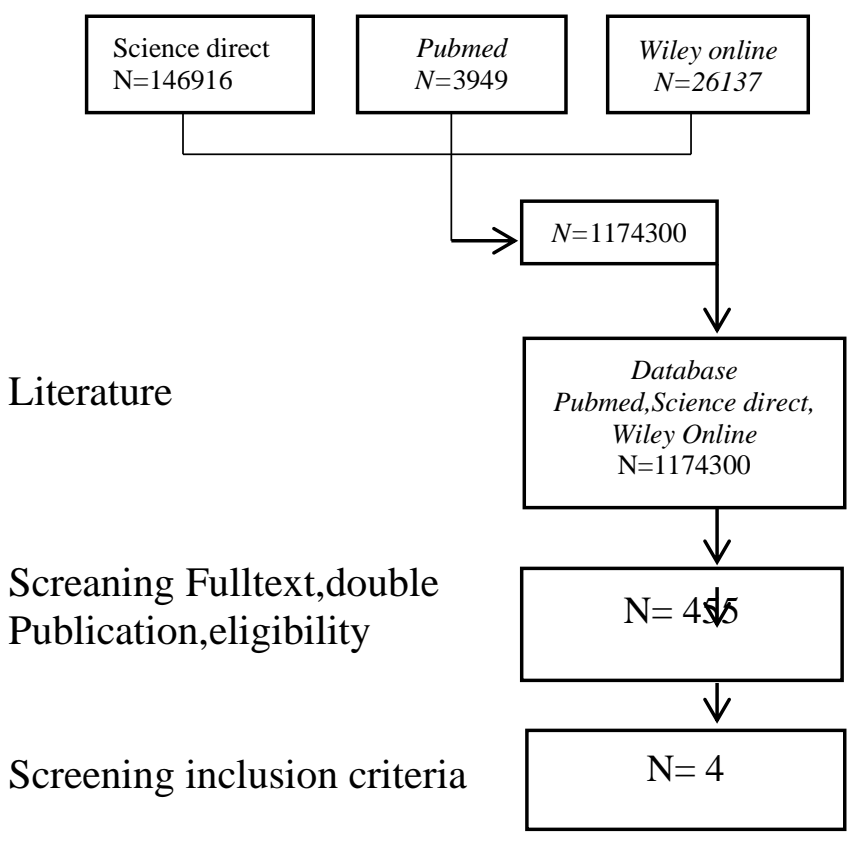

Figure 1: PRISMA Flow Diagram

\section{Abstarction and synthetic data}

Theoretical review can be done by several synthetic methods (Pare, Trudel, Jaana, \& Kitsiou, 2014). Identify patterns, themes, variations and relationships with the constant comparison method to extract articles in the form of categories (Milles \& Huberman, 1994). The first step is to reduce data based on these objectives, the data is collected on one page to make it easier, the second step is to form a table to facilitate the comparison, then the data is extracted from the original source (Pluyye \& Hong, 2014).

\section{RESULT}

Based on the search inclusion and exclusion criteria found 4 articles. This study relies on self-report instruments as well as reports on thoughts, feelings and actions related to clinical situations. The research method used is Mixed method with the results of quantitative analysis which is significant in clinical experience at site 127.76 and site 2 $17.85(p<, 05)$. RM-ANOVA test results are missing. significant interactions in the institution premises $n$ reflection from time to time, but after being checked for involvement of self-reflection effect from time to time to all participants found significant data $\mathrm{F}(2,34)=7: 24, \mathrm{p}<.002$, research it supports the approach reflective practice (Asselin \& Fain, 2013). Another study involved 244 nurses, using the cross sectional survey study method. As conclusion Nurses consider activities of development of personal as mentoring and clinical supervision can be connected improvement related to teamwork (Milles \& Huberman, 1994). Meanwhile, the description of reflection techniques as an effort to improve professionalism using qualitative methods with a phenomenological approach, this study found a model called the model of professional development in nursing(Gustafsson, 2004). An overview of the strengths and weaknesses of the method of reflection in practice and learning (Nursing and Midwifery 


\section{STRADA Jurnal Ilmiah Kesehatan}

DOI: $10.30994 /$ sjik.v9i2.306

ISSN: 2252-3847 (print); 2614-350X (online)

Vol.9 No.2 November 2020 Page.332-337

Board of Australia., 2016). As well as research conducted at Redcliffe Hospital and Cabolturre found reflective practice as a focus group model (Finch, 2016). Another study involved 127 nurses at University Hospital Quebec on evaluating reflective practice on nurses' attitudes (Dube \& Ducharme, 2014).

\begin{tabular}{|c|c|c|c|c|}
\hline No & Author & Judul Penelitian & Metode/Instrumen & Hasil \\
\hline 1 & $\begin{array}{l}\text { Asselin, M. E., \& } \\
\text { Fain, J. A. (2013 }\end{array}$ & $\begin{array}{l}\text { Effect of Reflective } \\
\text { Practice Education on } \\
\text { Self-Reflection, } \\
\text { Insight, and Reflective } \\
\text { Thinking Among } \\
\text { Experienced Nurses }\end{array}$ & Mixed Method & $\begin{array}{l}\mathrm{p}<.002, \text { There is a } \\
\text { relationship between } \\
\text { reflective approaches }\end{array}$ \\
\hline 2 & $\begin{array}{l}\text { Welp, Johnson, } \\
\text { Nguyen, \& Perry } \\
(2018)\end{array}$ & $\begin{array}{l}\text { The importance of } \\
\text { reflecting on practice: } \\
\text { How personal } \\
\text { professional } \\
\text { development activities } \\
\text { affect perceived } \\
\text { teamwork and } \\
\text { performance }\end{array}$ & $\begin{array}{l}\text { Cross sectional } \\
\text { survey study }\end{array}$ & $\begin{array}{l}\text { Self professional } \\
\text { development can be } \\
\text { influenced } \\
\text { teamwork activities and } \\
\text { discussions }\end{array}$ \\
\hline 3 & $\begin{array}{l}\text { Gustafsson } \\
\text { (2004). }\end{array}$ & $\begin{array}{l}\text { Reflection, the way to } \\
\text { professional } \\
\text { development?, }\end{array}$ & $\begin{array}{l}\text { Interview dan } \\
\text { fenomenografi }\end{array}$ & $\begin{array}{l}\text { The method of } \\
\text { reflection can increase } \\
\text { work professionalism }\end{array}$ \\
\hline 4 & Dube (2014) & $\begin{array}{l}\text { Evaluation of a } \\
\text { Reflective Practice } \\
\text { Intervention to } \\
\text { Enhance Hospitalized } \\
\text { Elderly Care }\end{array}$ & Mixed Method & $\begin{array}{l}\text { Reflective practice as } \\
\text { developing professional } \\
\text { attitudes of nurses } \\
\text { towards more mature } \\
\text { people }\end{array}$ \\
\hline
\end{tabular}

Table 1 : Synthetic data

\section{DISCUSSION}

The reflection method is carried out in the nursing practice environment, reflection discussion is one of the many development of practical methods, the development of RCD in the health environment especially nurses is believed to be able to reduce the gap in theory and practice, this is in line with research that reveals if there is no difference between theory and practice it will reduce the risk of bad and mistakes in acting. This research more broadly discusses the structured reflection model or RCD (Asselin \& Fain, 2013). Implementation and effectiveness of RCD is done at least once a month. RCD must be routinely carried out in order to minimize errors of action, in nursing management RCD must be planned and proposed to the leadership of the hospital.

Kolb "s model is a reflective technique, this model is divided into the following stages: the stage of concert experience, reflective observation, abstract conceptualization 


\section{STRADA Jurnal Ilmiah Kesehatan}

DOI: $10.30994 /$ sjik.v9i2.306

ISSN: 2252-3847 (print); 2614-350X (online)

Vol.9 No.2 November 2020 Page.332-337

and active experimentation (Dube \& Ducharme, 2014). Concert experience, namely health workers or nurses describing events and problems that occur, after that nurses do reflective observation that is thinking about past experiences, then having discussions with colleagues or abstract conceptualization and finally looking for new knowledge with active experimentation. Kolb's model is also beneficial for personal professional development. Other research suggests that reflective methods are useful in the frequency of participation, professionalism and teamwork, while professional personal development can be done by building a culture of reflective thinking. An effective RCD must have the support of the discussion participants (Welp, Johnson, Nguyen, \& Perry, 2018).

The support of discussion members influences the results of the RCD, but one very important thing is organizational support in this case the head of the hospital or the head of nursing management.

One of the obstacles in the implementation of RCD is the lack of support, sometimes Nurses schedule RCD but the rooms and other facilities do not support (Amir, Irwan, \& Saleh, 2019).

This obstacle certainly influences the effectiveness of RCD implementation. The role of the Head of the nursing midwife and management of the Hospital will motivate nurses to routinely carry out RCD so that the transformation of knowledge can be realized.

RCD is designed to foster a culture of sharing and enhancing knowledge (Gustafsson, 2004). The research, developed by Finch (2016), concludes that engaging in reflective discussions not only helps you to recognize yourself but helps others to recognize your personality, discussions help relationships, foster work enjoyment, and support shared commitment in the organization. In addition, the preparation of discussion participants is the most important factor in the effectiveness of the discussion (Dube \& Ducharme, 2014).

Other research supports the practice of reflection as a method or tool that connects the practice of experience and knowledge, through reflections of conscious self-conscious reflectors, reflection helps them improve clinical skills (Tashiro, Shimpuku, Naruse, Maftuhah, \& Matsutani, 2012).

\section{CONCLUSION}

According to some RCD researches are a very good reflection method applied to the environment of nursing practice for example, hospitals and health centers. These studies reveal positive RCD results that can improve professionalism and support commitment among nurses.

RCD can be done at least once a month, the role of discussion participants is divided into moderators, presenters and participants. The results of several studies reveal nurses get new knowledge from the RCD.

The implementation of RCD also requires support, the participation of all elements influences the outcome of the discussion so that participant involvement at the leadership level is the key to running the RCD well.

\section{REFERENCES}

Amir, H., Irwan, A. M., \& Saleh, A. (2019). Gambaran Pelaksanaan Diskusi Refleksi Kasus (DRK) Dalam Mendukung Peningkatan Pengetahuan Dan Profesionalitas Perawat. Jurnal Keperawatan Muhammadiyah, , 4(2).

Asselin, M. E., \& Fain, J. A. (2013). Effect of Reflective Practice Education on SelfReflection, Insight, and Reflective Thinking Among Experienced Nurses. Journal 


\section{STRADA Jurnal Ilmiah Kesehatan}

DOI: $10.30994 /$ sjik.v9i2.306

ISSN: 2252-3847 (print); 2614-350X (online)

Vol.9 No.2 November 2020 Page.332-337

for Nurses in Professional Development, 29(3),111-

119,doi:10.1097/NND.0b013e318291c0cc.

Berterö, C. (2010). Reflection in and on nursing practices- how nurses reflect and develop knowledge and skills during their nursing practice . International Journal of Caring Sciences, 3(3), 85-90.

Benner. (1984). From Novice to Expert: Excellence and Power inClinical Nursing Practice. Addison-Wesley, Menlo Park, CA.

Dawber, C. (2012). Reflective practice groups for nurses:A consultation liaison psychiatry nursing initiative: Part 1 - the model. International Journal of Mental Health Nursing, 22(2):135-44. doi: 10.1111/j.1447-0349.2012.00839.x.

Dube, V., \& Ducharme, F. (2014). Evaluation of a reflective practice intervention to enhance hospitalized elderly care. . Journal for Nurses in Professional Development, 30(1),34-41,doi:10.1097/ NND.0000000000000028.

Finch, A. (2016). Revalidation and reflective practice. Nursing Management, 23(1):22-5. doi: $10.7748 / \mathrm{nm} \cdot 23.1 .22 . \mathrm{s} 26$.

Gustafsson. (2004). Reflection, the way to professional development. Clinical Nursing Issues, doi: 0.1046/j.1365-2702.2003.00880.x.

Kesehatan, K. (2005). Pedoman Pengembangan Manajemen Kinerja Perawat dan Bidan . Jakarta.

Milles, \& Huberman. (1994). Qualitatative DATA Analysis.Thousand Oaks. CA: Sage Publications.

Nursing and Midwifery Board of Australia. (2016). Nursing and Midwifery Board of Australia. Melbourne, Australia: Retrieved from http://www.nursingmidwiferyboard.gov.au .

Nursing of Midwifery Council. (2015). How to Revalidate with the NMC:Requirements for Renewing your Registration. London: NMC.

Pare, G., Trudel, M., Jaana, M., \& Kitsiou, S. (2014). Synthesizing information systems knowledge: A typology of literature. Information \& Management, 52(2),doi:10.1016/j.im.2014.08.008.

Pluyye, P., \& Hong, K. (2014). Combining the power of stories and the power of numbers: Mixed methods research and mixed studies review. Annual Review of Public Health, 35, 29-45. https://doi.org/10.1146/annurev-publhealth-032013-182440.

PPNI. (2016). Pedoman pendidikan keperawatan berkelanjutan (PKB) perawat indonesia (Ed 2). Jakarta.

Tashiro, J., Shimpuku, Y., Naruse, K., Maftuhah, \& Matsutani, M. (2012). Concept analysis of reflection in nursing professional development. Japan Journal of Nursing Science, 10(2),doi:10.1111/j.1742-7924.2012.00222.x.

Welp, A., Johnson, A., Nguyen, H., \& Perry, L. (2018). The importance of reflecting on practice: How personal professional development activities affect perceived teamwork and performance. Journal of Clinical Nursing, doi:10.1111/jocn.14519. 